KORINEK Beáta Zsófia

DOI: 10.15170/DIKE.2018.02.02.07

Tudományos segédmunkatárs

PTE ÁJK

\title{
A családon belüli erőszak múltja és jelene Magyarországon
}

\section{Domestic Violance in Hungary. Past ans Present}

Violence and aggression have existed since prehistoric times. According to Konrad Lorenz' it is a key to our survival. Yet its long-term existence, overgrowth can have unpredictable consequences for several generations in advance. If the family, this protective, sheltering nest is the scene of the battlefield, it is particularly damaging for both the individuals and the community. Its characters are trying to solve secretly, silently the processes which is taking place at home, and to protect the nest through this. Recognition and intervention would be particularly important when there is something dysfunctional in the smallest unit of society because of its closeness, the most vulnerable, such as children, can suffer long-lasting and life-threatening damages. One of the prerequisites for the harmoniously functioning of a buman community is that we pay attention to each other, know our potential, notify pros and cons most preferably in time. Individual and social responsibility must be taught to community members to make everyone feel that they are giving hands to the weaker. Dealing with dysfunctions in a timely manner can free up society from long-term burdens. The present paper aims to present domestic and foreign methods and opportunities in the hope of a more non-violent social vision.

Keywords: domestic violence, children, family, society, past and present, music therapy, connectionanalysis, voluntary

\section{Bevezető}

Erőszak és agresszió a történelem előtti idők óta létezik. Konrad Lorenz szerint túlélésünk záloga. ${ }^{1}$ Tartós megléte, túlburjánzása akár több generációra, azonban előre láthatatlan következményekkel járhat. Ha a család, a védő-óvó fészek, a csatatér színtere, az különösen káros az egyénre és a közösségre egyaránt. Szereplői igyekeznek titokban, csendben megoldani, eltakargatni az otthonban zajló folyamatokat. A felismerés és a beavatkozás azonban különösen fontos lenne, hiszen a társadalom legkisebb egységében múködik valami diszfunkciósan: zártsága miatt a legkiszolgáltatottabbak, a gyermekek², tartós és egész életükre nagy kiható károkat szenvedhetnek.

1 LORENZ, Das sogennante Böse 30-55.

2 2011-ben az Európa Tanács elfogadta „A nök elleni és családon belüli erőszak megelözéséröl és felszámolásáról” szóló Egyezmény. Hazánk ezt még nem ratifikálta, de az Új Büntetőtörvénykönyv mellett a T/11105. számú törvényjavaslat indoklása nevesítetten hivatkozik rá. Az Isztambuli Egyezmény célként tűzi ki, hogy megváltoztassa azokat az attitűdöket, sztereotípiákat, melyek lehetővé teszik a nők elleni erőszak elfogadását. Ennek sikeréhez elengedhetetlen - az oktatás és a képzés mellett - a társadalom legszélesebb rétegeinek elérése, hogy tudatosítani lehessen az erőszak különböző formáinak szélesspektrumú traumatizáló hatását. 
Egy közösség harmonikus múködésének feltétele, hogy a közösség tagjai figyeljenek egymásra, ismerjék a lehetőségeinket és jelezzék, ha bárki közülük nehézségekkel szembesül. Az egyéni és társadalmi felelősségvállalásra, azaz a probléma észlelésére és az ennek megfelelő cselekvésre tanítani kell a közösség tagjait. A diszfunkciók időben észlelése és kezelése hosszútávú terhektől szabadítja meg a társadalmat. Jelen írás a hazai és külföldi módszereket, lehetőségeket kívánja bemutatni egy erőszakmentesebb társadalmi jövőképben bízva.

A Pécsi Tudományegyetem Állam- és Jogtudományi Kar Családjogi és Szociális Jogi Csoportja 2010 óta, minden szemeszterben elindítja a „Diákok a gyermekekért” elnevezésű önkéntesprogramját. A képzés keretében a joghallgatók heti rendszerességgel járnak önkéntes munkát végezni valamely pécsi, gyermekekkel foglalkozó intézménybe. Pszichológus segítségével szintén hetente szupervíziós foglalkozást is tartunk a hallgatók számára, annak érdekében, hogy a diákok szigorú keretek között, de elmondhassák élményeiket a gyerekekkel Az általuk megélt események feldolgozását, értelmezését segítik ezek a foglalkozások. A program célja kettős, egyrészt fő feladata a segítségnyújtás a gyerekek felé, másrészt viszont diákjaink érzékenyítése a nehezebb sorsúak irányába, ők, vagy hasonló sorsú embertársaink előfordulhat, hogy jövőbeli ügyfeleik lesznek majd. A társadalmi felelősségvállalás iránti érzékenyítés küldetése ezeknek az óráknak. Cél, hogy kialakuljon a fiatalokban egyfajta természetes odafordulás és kötelességtudat a másik ember felé. Fontos megértetni a fiatalokkal, hogy felelősei vagyunk a tágabb környezetünkben élők körülményeinek javulásáért. Valamilyen formában mindenki tud segíteni a nálánál elesettebbeken, vagy tudja a problémát jelezni, ha a képességeit és lehetőségeit meghaladó ügyről van szó. Az emberi kapcsolatokhoz hasonlóan az egyes szakterületek között is előfordulnak nehézségek. Ezért fontos az egyes szakterületek közeledése egymáshoz, különösen akkor, amikor emberi sorsok jobbítása a cél. A pécsi jogi karon ezzel az önkéntes szemináriummal végezzük a hídépítést: hidat próbálunk emelni a jogászok és a szociális szférában dolgozók, a hallgatóink és a nevelt vagy fogyatékos otthonban élő gyermekek, fiatalok között, úgy hogy heti rendszerességgel órákat töltenek együtt játékkal, sporttal, vagy csak beszélgetve. Ezt a tevékenységet készíti elő az is, hogy a diákokkal minél több olyan közvetítői/mediációs módszert tanítunk meg, amely a hagyományos bírói út mellett vagy helyett, lehetőséget biztosít a konfliktusok megoldására, akár jóvátétellel, akár bocsánatkéréssel.

A családjog által szabályozott jogviszonyok lényegesen különböznek az egyéb, más területek által lefektetett magánjogi jogviszonyoktól. Hisz a családjog többnyire - leszámítva a közigazgatási jellegű normákat - személyi viszonyokból illetve erkölcsi normákból áll, és az utóbbiak különösen nehezen szabályozhatók. Minden családnak megvan a maga sajátos, egyedi működési módja. A polgári törvénykönyvről szóló 2013. évi V. tv. IV. könyve (Családjogi Könyv) ${ }^{4}$ hangsúlyosan védi a családok autonómiáját és szabályai csak a legszükségesebb mértékben beavatkozók. Amíg egy család múködése az egyént vagy a közösséget nem érinti negatívan, addig sok minden megvalósulhat, gyakorlatilag észrevétlenül. Láthatatlan marad a hatóságok, segítőszervezetek számára az a család, amely egyébként diszfunkciósan múködik. Mindnyájan családban élünk vagy éltünk, és ez az érintettség egy nagyon fontos pszichológiai védekező, hárító

\footnotetext{
${ }^{3}$ KORINEK, A családból fakadó erő 47-49.

${ }^{4}$ KŐRÖS, Az új Ptk. magyarázata III/IV. 27-38.
} 
mechanizmust indít be mindannyiunkban, amikor a közvetlen környezetünkben egy egyén vagy egy közösség segítségre szorul. ${ }^{5}$ A családi erőszak egy olyan jelenség, amit a családtagok különösen szégyellenek. Magas a látencia, mert a szereplők titkolják, takarják, ameddig csak lehetséges, de mégis a családjog által szabályozott összes részterületet negatívan befolyásolja a kényszerházasságoktól kezdve a gyermekek jogellenesen külföldre viteléig és a szülői felügyeleti jog csorbulásáig.

Doktori kutatásom fô témája az egyéni és családi diszfunkciók vizsgálata, megoldások keresése. A családon belüli erőszak tünete a kezeletlen diszfunkcióknak, egyéni és közösségi szinten is. Mindnyájan családban élünk, a család, mint a társadalom legkisebb legérzékenyebb csoportja tükrözi legintenzívebben azokat a nehézségeket, melyek a családban lappanganak, vagy épp külső társadalmi csoportokból kúsznak be. A családi hierarchiának életkoránál, fejlettségénél fogva a gyermek a legkiszolgáltatottabb tagja ${ }^{6}$. Amennyiben egy kisgyermek már korán súlyos traumákat él át, és ennek feldolgozásához nem kap szakszerű segítséget, esetleg az évek előre haladtával egyre több sérelem éri, lehet, hogy később nem lesz képes belső feszültségén úrrá lenni, így maga is könnyen elkövetôvé válhat. A családon belüli erőszak minden társadalmi réteget érintő jelenség. A megfelelő védelmi, megelőző rendszer tényleges kiépítése hosszú ideje égető probléma Magyarországon is. A posztszocialista országokban, így Magyarországon is, a családvédelemben sajnos még tapasztalható elmaradás. Ahhoz, hogy ezt a hátrányt mielőbb behozhassuk, a veszélyeztetett gyerekeket hatékony segítőmódszerekkel is támogatnunk kell. Hiába vannak megfelelő jogszabályok, ha a megvalósítás során a gyakorlati szakemberek súlyos nehézségekkel küzdenek.

\section{A vizsgálat fő kérdései}

Az alábbi tanulmányban a következő kérdésekre keresünk válaszokat: 1. Miként befolyásolták a polgári modernizáció korának, majd az 1948 és 1998 közötti korszaknak a társadalmi és jogi változási a családokat és a gyermekeket? 2. Miben különbözik nyugati szomszédjaitól a fiatal demokráciával rendelkező magyar társadalom? 3. Megoldást nyújthat-e a nyugat-európai országokban már múködő és amerikai gyökerekre visszavezethető intervenciós rendszer átvétele? 4. Miért nincs még kellően hatékonyan múködő fellépés a veszélyben lévő családok érdekében, miközben európainak tekinthető jogszabályi háttérrel rendelkezünk? Zárásul két figyelemre méltó magyar segítő módszert mutat be a tanulmány, melyek előremutató és beépíthető elemei lehetnek egy épülőben lévő, relatív fiatal demokráciával rendelkező, egykor a szovjet-blokkhoz tartozó ország szociális hálójának. Egy adott korszakban a családok múködéséről vagy épp múködésképtelenségéről három témakört vizsgálva kaphatunk képet. Milyen pozíciót foglalt el a (házasságból vagy házasságon kívül született) gyermek a családban és a társadalomban, mik voltak az elfogadott szülői magatartások és hogyan reagált a társadalom a nem megfelelő szülői magatartásra.

\footnotetext{
${ }^{5}$ KORINEK, A stalkingról 117-130.

${ }^{6}$ KORINEK, Egyenlő esélyek büntetéssel? 109-122.
} 


\subsection{A gyermekvédelem fejlődése itthon és Európában ${ }^{7}$}

Európában a polgári társadalom kialakulásával egyidőben született meg a gyermekkor eszméje, valamint az igény a gyermek fejlődéséhez elengedhetetlen oktatásra és nevelésre. A gyermek megítélése körüli pozitív változások elsősorban morális elveknek és a társadalom szerkezetében bekövetkezett változásoknak tudhatók be. A polgárság és a polgári életforma részévé vált a gyermekek tudatos, szervezett formában, közösségi iskolákban történő képzése, a jövő generációjának építése. ${ }^{8}$ Ennek az átalakulásnak köszönhető, hogy kitolódott a gyermekkor fogalma, és nagyobb figyelmet fordítottak a gyermekek egészségügyi és higéniai körülményeikre is. A magas gyermekhalandóság megállitása illetve visszafordítása azért is fontos törekvés volt, mert a polgárság körében jellemzően csökkent a gyermekvállalási hajlandóság. A lakosság nagyobb része ugyanakkor változatlanul nagy szegénységben, a fizikai túlélést éppen biztosító körülmények között élt. Az ipari társadalom kialakulásával a termelés nagyipari méreteket öltött, vagyis az egyénre, mint önálló munkavállalóra volt szükség. A gazdaságnak érdekében állt, hogy a nők és gyermekek is tömegével dolgozzanak az iparban. A nagyüzemi termelés elterjedésének következménye volt a családok termelői tevékenységének csökkenése, és a munkaerő áruba bocsátásából származó létfenntartás. Változás következett be az állam és az egyén viszonyában is. A liberális jogállam, mint a modern állam prototípusának egyik absztrakciója, ${ }^{9}$ a családra bízta a felelósséget tagjaiért. Az állam és a család viszonyának legfőbb jellemzője a volt, hogy az állam elvárta a családi kötelezettségek teljesítését, de az ezzel kapcsolatos nehézségek leküzdésében nem igen segített. A gyermekek gondozása, nevelése teljes mértékben a családok vállát nyomta, ahogy a családi konfliktusok megoldásának terhe is. A gyermekek családon belüli helyét az európai jogfejlődésben többnyire a 19-20. század fordulójáig az atyai hatalomnak való alávetettség jellemezte, ami természetes módon foglalta magába a testi fenyítés jogát is.

Az urbanizáció folyamatával párhuzamosan elterjedő tömeges városi szegénységet a társadalom közömbösen szemlélte, és nem reagált a gyermekek elleni erőszakra sem. Általánossá vált az a nézet, hogy a szegénység bűn, és egyben újabb bűnök forrása. Különbséget tettek az „igazán érdemes munkásosztály” és a „gyalázatos sqegények” között. A szegénységet egyéni kudarcnak, szégyennek tartották. Az állam csupán akkor lépett fel, ha veszélybe került a munkaerő újratermelése vagy rendelkezésre állása, illetve ha a család alapvető feladatát nem teljesítette. Ekkor azonban kiemelte a családtagot a közösségből, és a felnőttet a dologházba, a gyermeket a menhelyre küldte. A gyermek, mint áldozat problematikája kevéssé volt porondon; Nigel Parton szerint ez a kérdés jellemzően csak egy-egy társadalmi réteg vagy csoport kezdeményezésére kapott teret. Így például a 19. század közepén kialakuló angol gyermekvédő mozgalom mögött a középosztálybeli asszonyok álltak, akiket a gyermekek megmentésén túl saját társadalmi pozíciójuk megerôsítése is motivált. A két világháború között a hangsúly a társadalom védelmén maradt, amelyre fenyegető veszélyként nehezedett a gyermek- és fiatalkori bűnözés. A korszak büntetőjogi vívmányainak köszönhetően elfogadottá vált, hogy a felnőttektől eltérő módon kell kezelni a fiatalkorú elkövetőket, és velük szemben elsősorban nevelő jellegú intézkedéseket kell alkalmazni. A

\footnotetext{
${ }^{7}$ Vö. KEREZSI, A védtelen gyermek 11-25.

${ }^{8}$ KOSÁRY, Az oktatásügy a haladó törekvések hullámvölgye idején 226-240.

${ }^{9}$ HerGER, Szakrális kontra szekuláris értékek a polgári modernizáció korában 33-44.
} 
gyermekvédelemben elsősorban a kiskorú sértettek nem megfelelő környezetből való kiemelését alkalmazták, és nem a prevenciót vagy a rehabilitációt. Ha a szülők alapvető kötelességüket a gondozás-nevelés terén nem jól látták el, az állam súlyosan megbüntette őket.

A gyermekvédelem szükségességének gondolata a nyugat-európai trendnél később jelentkezett itthon. Ezért nem meglepő, hogy Pauler Tivadar 1869-ben kiadott büntetőjogi tankönyvében - az 1861 után helyreállított, tradicionális magyar büntetőjog tényállásait - a szülők sértését illetve megverését, a rokongyilkosságot, a gyermekölést, a magzatelhajtást és a gyerekkitételt hosszan tárgyalta a szerző, de a gyermekvédelem gondolata nem került még elő, miközben a családtagok sérelmére elkövetett bűncselekmények hátterével részletesen foglalkozott Pauler. ${ }^{10}$ Löw Tóbiás kommentárja megállapította egyhelyütt a családok kiszolgáltatottságát, amennyiben olyan erkölcsileg elítélendő cselekmény áldozatává váltak, mely a társadalom előtt nehezen vállalható, és szégyen övezi. Az egyén családban történő áldozattá válásáról azonban nem esett szó. A hatóságok ellenben csak akkor tudnak cselekedni, állapította meg Löw, ha a károsítottak ,felderitik a körülményeket”. „Tagadhatatlan továbbá, hogy némely, habár súlyos büntett, az általa megsértett család becsületét, békéjét és nyugalmát érinti, ugy, hogy a család akarata elleni beavatkozása, ennek szerencsétlenségét még nagyobb mértékben növelné. Az állam nem mellöz̧heti ily esetben a családi élet tekinteteit, s a nyugalom érdekében báttérbe vonulván, a sujtottak fellbivásától tételeri fel intézkedését." "11 A szerző leírta továbbá, hogy emiatt - a szégyen és a meghurcoltatástól való félelem okán - számos esetben nem derültek ki súlyos bűncselekmények, vagyis létező problémaként utalt a magas látenciára. ${ }^{12}$ Feltételezhetôen mind a családon belüli, mind pedig a családokat mint közösséget érintố esetekre is gondolt.

A polgári fejlődés következtében kialakult társadalmi nehézségekkel Magyarország viszonylag később a 19-20. század fordulóján szembesült. A hagyományos társadalmi kontroll rendszere darabjaira széthullott, ami sokféle társadalmilag kedvezőtlen jelenség kialakulását eredményezte. A gyermekhalandóság nagyon nagy volt, de jelentősen nőtt az elhagyott és csavargóvá vált gyermekek száma, a fiatalkori bűnözés is riasztó méreteket öltött. Hazánkban az 1901. évi VIII. és XXI. törvénycikkek a menhelyek felállítását illetve az elhagyott gyermekekről való gondoskodást szabályozták. Az állami menhelyek voltak a gyermekvédelem központi intézményei, ahová ugyanúgy bekerült az árva, az elhagyott, az elhanyagolt, de az adott esetben már valamilyen bűncselekményt is elkövetett gyermek. A gyermekvédelmi feladatok differenciálása tehát nem történt meg. Így a rendszerbe bekerült gyermekek további viktimizálódása szinte garantálható volt, miközben a családok megsegítéséről szó nem esett. A gyermekvédelmi rendszer kialakítását a társadalom megóvása indokolta a devianciától, az antiszociális magatartásoktól, nem pedig gyermekek felé irányuló védelmi célzat. Nagyiványi-Fekete Gyula már 1893-ban megfogalmazta, hogy épp azért lenne fontos a „specziális nevelo intézetek felállitása”, mert a társadalmi változások következményeként olyan fiatalkori deviáns magatartások jelentek meg, melyek kezeletlensége veszélyes a társadalomra. ${ }^{13}$ Balogh Jenő összefoglalta azokat a tényezőket és körülményeket, amelyek szinte örökletessé teszik a bűnelkövetést a „munkás és proletár-néposztályok rétegeiben”. A családi élet kötelékei erősen meglazultak, a fiatalkorúak a korábbi időkhöz képest sokkal inkább

\footnotetext{
${ }^{10}$ PAUler, Büntetőjogtan 140-185.

${ }^{11}$ LÖW, Büntetőjog I. 586-589.

${ }^{13}$ NAGYIVÁNYI FEKETE, Az elhagyatott gyermekek és a fiatalkorú bűntettesek gondozása 323-324.
} 
rákényszerültek a kereső munka végzésére. Jellemzővé vált az asszonyok háztartáson kívüli munkavégzése, és a leterhelt, rossz körülmények között élő családok nem egyszer elhanyagolták a kisgyermekek nevelését és gondozását. A rendkívül rossz körülmények velejárójának látta Balogh a züllést, az alkoholfogyasztást, melyek sokszor a „büncselekménynek is okai lettek”. ${ }^{14}$

Látható, hogy a családok megsegítése szóba sem jött a büntetőjogi szakirodalomban, vagyis a prevenció nélküli büntetô intervenció a kort jellemző állami beavatkozó, rendteremtô válasz volt. Nem vették figyelembe azt a tényt, hogy jellemző módon éppen a külső társadalmi átalakulások eredményeként estek szét a családi közösségek és tűntek el a társadalom múködéséhez is elengedhetetlen belső családi normák. A különböző egyházi és társadalmi szervezetek karitatív tevékenységére úgy épített az állami gyermekvédelem, hogy saját felelősségvállalásának határait és garanciáit nem jelölte ki, vagyis az együttműködés és a szolgáltatás kiszámíthatatlan és esetleges volt, ami csakis a rászoruló gyermekek és családjaik helyzetét rontotta tovább.

A második világháború idején a gyermekvédelem első számú feladata a rengeteg magára maradt, elveszett, árva gyermek megmentése volt. Őket nevelőszülőknél illetve gyermekotthonokban helyezték el. Pénz nem volt új otthonok létrehozására, így az arisztokráciától elvett kastélyok szolgáltak a gyermekek otthonául. Az ötvenes években az állam arra törekedett, hogy a gondozott gyermekek lehetőleg gyermekotthonokban éljenek. Ennek egyrészt a nevelőszülői rendszerről kialakult negatív megítélés, ${ }^{15}$ másrészt ideológiai magyarázata is volt. A közösséget tartották a legnagyobb értéknek, bíztak abban, hogy a szakértelemmel történő közösségi nevelés helyettesíteni tudja a nem gondoskodó családot a gyermek életében, sôt állami segítséggel akár értékesebb állampolgárokat is nevelhetnek az adott gyermekből a társadalom számára. XI. Pius pápa „Quadragesimo anno" című mûvében erről így ír, „mindaðt, amit egy kisebb és alacsonyabb szinten szervezoódött közösség képes végrehajtani és ellatni, egy nagyobb és magasabb szinten szervezőöött társulásra átháritani jogszerütlenség és egyúttal súlyos bün." ${ }^{\text {"16 }}$ A pápai üzenetre Böje Csaba ferences atya hívta fel a figyelmet. A Szent Ferenc Alapítvány számos házában több mint 2500 gyermek családias, 5-6 fős csoportokban nevelkedik. Az általa kitalált gyermekvédelmi központoknak iránymutatójává vált ez a XI. Piustól származó gondolat.

Kétségtelen, hogy a nők és rajtuk keresztül gyermekek jogállását erőteljesen befolyásolta a nőmozgalmi törekvések hatékonysága. Az iparosodás korának új kihívásai közé tartozott a háztartáson kívül elhelyezkedő nők munkajogi helyzete, ezzel kapcsolatban az oktatáshoz való joguk, politikia jogaik és családjogi jogállásuk is. 1857-ben Caroline Elisabeth Sarah Norton nyilvánosságra hozta saját bántalmazással átszőtt házasságát, melyből 1836-ban megpróbált elmenekülni. Férje kizárta otthonukból, megvonta gyermekük láthatását tőle. Az esetet követő társadalmi vita hatására Angliában jelentősen módostult a nők felügyeleti joga, valamint bontójogi és házassági vagyonjogi jogállása (Custody of Infants Act 1839, Matrimonial Causes Act 1857, Married Women's Property Act 1870), ${ }^{17}$ de nem feledhető az sem, hogy Anglián kívül is megélénkült a nők jogállásának jovításáért folyó politikai és társadalmi vita. ${ }^{18}$

\footnotetext{
${ }^{14}$ BALOGH, Fiatalkorúak és büntetőjog 5-10.

${ }^{15}$ Lásd a MÓRICZ Zsigmond „Árvácska” című művében leírt társadalmi környezetet.

${ }^{16}$ Lásd XI. Pius pápa Quadragesimo anno... kezdetű enciklikáját.

${ }^{17}$ CAINE, English Feminism; PERKIN, Women and Marriage in Nineteenth-Century England.

${ }^{18}$ BEAVOIR, A második nem, 24-40.
} 
Magyarországon a nőmozgalom első hulláma a 20. század elején indult el ${ }^{19}$ míg a második hullám, ami az Amerikai Egyesület Államokban az 1960-as években indult, hazánkat már nem érte el. Ebben az időszakban kezdtek felfigyelni a családon belüli erőszak problémájára és annak kezeletlenségére. Itthon a szocializmus évtizedei sajátos helyzetet teremtettek. Formálisan érvényesült a nemek közötti egyenlőség, a társadalmi mentalitás azonban a tradicionális családmodelltôl nem sokban mozdult el: sosem kérdőjeleződött meg az a nézet, hogy miközben a nő is munkavállaló, egyben a házimunka és a gyermeknevelés is az ő feladata. Ha egy család veszélyes környezetnek bizonyult egy gyermek számár az 1950-es évek Magyarországán, akkor az állam által alkalmazott egyetlen módszer a gyermekeket védő hatósági intézkedés, a családból való kiemelés volt. A családok nem segítséget kaptak, hanem probléma esetén az állam beavatkozott. A nők tömeges munkába állását nem támogatták szolgáltatások, melyek kisegítették volna a több helyen is helytállni kényszerülő nőket. A születések száma drámaian lecsökkent, legalizálva lett az abortusz és egyre fontosabb lett az anyagi jólét is.

Összefoglalva megállapítható, hogy a múltból eredeztethető az a társadalmi elvárás a család felé, hogy a belső problémáit, legyen szó anyagi vagy érzelmi jellegû krízisről, oldja meg önállóan. A családokban zajló konfliktusok társadalmi megítélése és a megoldáskeresés előremozdítása érdekében az egyénnek és a közösségnek is fontos, hogy a családba külső erő is belenyúljon, csak nem mindegy, hogy mikor és hogyan. A kései, szankcionáló beavatkozás generációkra meghatározhatja a családtagok sorsát. A családi erőszak tehát nem magánügy, és a hatása nem csupán a családban érvényesül. Ennek az átalakulási folyamatnak a megértése jelenleg is zajlik, azt azonban nehéz megmondani, hogy hol van az egészséges határ az egyéni és a közösségi érdek között, miközben nyilvánvaló, hogy mekkora erővel alakítja egyik a másikat.

\subsection{A közjogi és politikai viszonyok hatása a családmodell alakulására}

Vallom a paracelsusi alapelvet, ${ }^{20}$ amely szerint amilyen a mikrokozmosz, olyan a makrokozmosz is. A társadalom szerkezete erősen meghatározza a kisebb közösségét, vagyis a család felépítését is. Ahogy a gyermek szüleitől vesz példát, gyakran hasonul hozzá, úgy a családi viszonyok alakulását is befolyásolhatja az állam és a társadalom viszonyrendszere. A magyar családmodell formálódására 1990 előtt hatása volt a nem demokratikus társadalmakra jellemző alá-fölérendeltségnek. ${ }^{21}$ Az ilyen társadalmakban az irányító hatalom rendszerint az uralkodó, vagy maga az állam, aki teljhatalommal bír alárendeltjei, jelen esetben a társadalom tagjai felett. Mindenre kiterjedően meghatározza a társadalmi működés szabályait, az ellenállást nem tû́ri és súlyosan megtorolja azt. Ez a társadalom tagjaira megfélemlítőleg hat. Ez az államforma többnyire csírájában fojtja el az egyén önállósodásra való mindenfajta törekvését. Az ember, mint jelenlegi vagy jövendő munkaerő, és nem, mint polgár fontos. ${ }^{22}$ Mivel a hangsúlyt a közjóra helyezik, a magánszféra, így a család múködése, a gyermekek jogainak védelme is háttérbe szorul, jórészt szabályozatlan.

\footnotetext{
${ }^{19}$ CSÁSZÁR, Nőmozgalmak a dualizmus-kori Magyarországon 117-128.

${ }^{20}$ http://www.rubicon.hu/magyar/oldalak/1493_november_11_paracelsus_szuletese

${ }^{21} \mathrm{~V}$ ö. HoRvÁTH, A szovjet család- és házasságjog.

${ }^{22}$ KEREZSI, A védtelen gyermek 45-48.
} 
A családok vonatkozásában egy nem demokratikus társadalom esetében mindez leképződik, és jól érzékelhetô az alá-fölérendeltségi viszony az irányító családfő és a neki alárendelt családtagok között. Előfordulhat, hogy a családfő szinte tulajdonosként rendelkezik hozzátartozói felett. Mivel ezekben a társadalmakban jogilag nem, vagy nem hatékonyan szabályozott az együttélés módja, a családfő maga dönthet a fegyelmezésről. A szocialista országokban a közösségi érdekektől vezérelve alapvető társadalmi elvárás volt, hogy mindkét szülő lehetőség szerint dolgozzon. ${ }^{23}$ A munkanélküliség ismeretlen volt, sőt a büntető törvénykönyvben szankcionálva volt az ún. közveszélyes munkakerülés, ezért az állam igyekezett a gyermeknevelést gyakran már a csecsemőkorú gyermekek esetében is levenni a szülők válláról. Ennek hatására a gyerekek nagy többsége már a legkorábbi életszakaszukat sem a családdal töltötte. Tény, hogy a személyiségfejlődés szempontjából a családban eltöltött idő rendkívül fontos. A közösségi lét hasznossága mellett az egyes gyermekre nem mindig jut annyi idő, mint a családokban. A nem demokratikus társadalmakban nem tulajdonítanak döntő jelentőséget az egyén önálló karaktere kialakulásának, ami nehezíti a magabiztos, önálló személyiség kifejlődését. A hangsúly elsősorban a közösségbe való beolvadáson van, azaz a közösség érdeke előbbre került, mint az egyéné. ${ }^{24} \mathrm{~A}$ zárt ajtók mögött zajló családi eseményeket az állam paradox módon túlzottan is magánügynek tekintette, csak nagyon súlyos esetekben avatkozott be. A válások számának a mai mutatókhoz képest alacsonyabb volta nem szükségképpen az akkori jobb viszonyokat mutatja, hanem sokkal inkább azt, hogy a demokráciával a nagyobb szabadság nagyobb felelősséget hoz magával, és ezzel együtt a gyorsan változó viszonyok rugalmasságot követelnek. Ebben a küzdelemben sokan alulmaradtak, és ez megviselte a családokat is. ${ }^{25}$

A demokratikus társadalmak családmodelljében mind ezekkel szemben azt látjuk, hogy nagyobb hangsúlyt kap az egyén és az irányító hatalom mellérendeltsége. A demokrácia fontos alapelve, hogy az individuum, mint polgár választójogával, szólásszabadságával élve beleavatkozhat a közösség életének irányításába, egyfajta kölcsönös kontroll alakulhat ki. A törvények egyértelmúen szabályozzák az irányítók és az irányítottak jogait és kötelességeit. Vagyis ezzel elkerülhetôbbé válnak a szélsőséges, kiszámíthatatlan megtorlások is mindkét fél részéről. Az elnyomott társadalmakkal szemben a demokráciákban kevesebb a jogilag szabályozatlan területe az életnek. Az egyéni értékek fontosságának nagyobb hangsúlyozásával az egyes ember önállósodása egyértelmúbbé vált, csökkent az integrálódás, a közösségbe olvadás, a családalapítási kedv, és ezzel párhuzamosan megnőtt a válások száma is. Napjaink jellemzője, hogy az állampolgár független, önálló életét nehezebben adja fel, mint generációkkal vagy akár egy generációval korábban. Ez a folyamat megmutatkozik a gyermekbántalmazási ügyek magas számában is. A demokratikus társadalmi berendezkedésű államok családjaira többnyire szintén érvényes a paracelsusi elv, vagyis a kis- és nagyközösségek szerkezetileg hasonulnak. Természetesen itt is vannak kivételek. A szülők és a gyermekek viszonya sokkal inkább mellérendelt, mindkét fél jogai és kötelezettségei jól

\footnotetext{
${ }^{23}$ ENGELS, A család, a magántulajdon és az állam eredete 69, 75-76.

24 A szovjet típusú családjog elméleti alapjaihoz lásd ENGELS, A család, a magántulajdon és az állam eredete 69. és 75-76. Ennek értékeléséhez lásd többek között NizSALOVSZKY, Gesetz und Wirklichkeit im sozialistischen ehelichen Gütterrecht 27.

${ }^{25}$ A házastársak családjogi jogállásáról lásd HERGER, A modern magyar házassági vagyonjog 339-354.
} 
behatárolhatók. Az egyén szabadsága, az önkifejezés joga nincs olyan határok közé szorítva, ahogy az egy elnyomott társadalomban, illetve családban megnyilvánulhat.

Több mint két és fél évtizeddel az ún. rendszerváltás után Magyarország még mindig a kétféle társadalmi berendezkedés kettős behatása alatt áll. Kamaszkorát éli a magyar társadalom, a serdülőkor pedig feszültségpont a gyermek- és felnőttkor között. Ezt megérteni és szép lassan megtanulni, együtt élni az örökséggel, ebben rejlik a mi különlegességünk, ez a mi másságunk a hagyományos nyugati demokráciákkal szemben. Az emberek hirtelen megkaphatták rég várt szabadságukat, de megszokott önállótlanságukra mindez veszélyt is hozott.

Az 1989-1990-es évek közjogi és politikai változásai előtt illetve után eltérést mutatnak a családi erőszakkal kapcsolatos felmérések eredményei is, ami a társadalmi berendezkedés kettős hatásának tükrében talán tisztábban értelmezhetô, mint anélkül. A magyar társadalomban különösen erős a magánszféra tiszteletben tartása. Gyakran még mindig egyfajta tulajdonosi státusz jellemzi a magyar embereket: a gyerek tulajdon, a feleség tulajdon. Következésképpen a szülő vagy házastárs vérmérsékletétől függ, hogy miként fegyelmezi hozzátartozóit. Talán épp a privátszféra túlzott tiszteletben tartásának lehet a következménye, hogy az erőszakot megélt vagy fenyegetett áldozatok részéről, de még sokszor az incidensről tudomást szerzők felől is nagy a bizalmatlanság. Gyakran tartózkodnak a külső segítség igénybevételétől, aminek a következtében az amúgy is magas látenciával rendelkező terület a szakemberek számára még nehezebben körüljárhatóvá válik.

Minden társadalomkutató számára nehéz megérteni a családi erőszak gyökereit. ${ }^{26} \mathrm{~A}$ rendelkezésre álló hazai és nemzetközi statisztikák azt mutatják, hogy az elkövetôk nagy többsége férfi. Az áldozati oldalon elsősorban a feminista csoportok adatai alapján-szinte kizárólag nők, másodsorban gyerekek szerepelnek. A legújabb magyar tudományos kutatások már foglalkoznak a férfiak családon belüli áldozattá válásával is. Bármely oldalról is nézzük, akármelyik szülő vagy felnőtt is legyen az áldozat, ha családban megtörtént erőszakról beszélünk, szinte kivétel nélkül a gyermek is mint áldozat érintett a konfliktusban, még ha csak szemtanúként is. Az ô áldozati szerepük kezelése a kutatásokban még mindig csak a második helyen szerepel. Holott számolni kell azzal, hogy ezeknek a konfliktusoknak hosszútávú következményeik vannak, és a gyermekszemtanúk személyiségükben őrzik majd ezeket az emlékeket. Családon belüli erőszak esetén, ha gyermek is érintett a konfliktusban, a hatóságok már nem automatikusan a gyermeket emelik ki környezetéből, mint ahogy az elfogadott mód volt a szocialista időkben, hanem elsősorban az erőszaktevôtt. $^{27}$

A munkám során arra a megállapításra jutottam, hogy az egyes újitások epicentruma általában az észak-amerikai országok valamelyike. Ezek reformjainak beindulásától számítva majd egy évtized kell, mire azok a nyugat-európai országokban is éppoly múködôképesen a társadalmi élet részévé válnak, és közel még egyszer ennyi idő szükséges, mire elérik az egykori keleti blokkot. Igaznak vélem ezt a feltevést a családon belüli erôszakkal kapcsolatos intézkedések bevezetésénél, a gyermek- és nővédelem, vagy épp a stalking ${ }^{28}$ kutatások kapcsán, de ugyanígy igaznak vélem az olyan közbiztonsági intézkedések megismertetésénél, mint a new yorki rendőrség által bevezetett ún. zéró tolerancia elve volt.

\footnotetext{
26 TAMÁSI, Bűnös áldozatok 32-40.

${ }^{27}$ HerCZOG, Gyermekbántalmazás 22-25.

${ }^{28}$ KORINEK, A stalkingról 117-130.
} 


\subsection{A civil és az állami szervezetek munkája és a kihívások}

Ahogy az 1970-es évek Amerikájában, az 1980-as évek Nyugat-Európájában, úgy az 1990-es évek Magyarországán is a nőmozgalmi csoportok által végzett figyelemfelkeltő munkák következtében történtek az első családon belüli erőszakkal kapcsolatos fellépések. Ezek a csoportok azóta már a nemzetközi nővédelmi programokba is bekapcsolódtak. Napjainkra további számos civil szervezet alakult, melyek anyaotthonok, menedékházak, krízisambulanciák, segítőcsoportok létrehozásán dolgoznak (pl. NANE, UNICEF, Hintalovon), valamint megfelelő segítőprogramokkal igyekeznek támogatni a vészhelyzetbe került rászorultakat.

Az államilag irányított segítô és megelőző feladatok ellátói közül kiemelendő a családok ügyével és a gyermekvédelemmel foglalkozó minisztériumi főosztályok munkája, valamint az ő irányításuk alatt múködô területi családsegítő központok tevékenysége. Feladatuk a veszélybe kerültek támogatása és a rehabilitációjuk koordinálása. A rendőrségen speciális megbízottak foglalkoznak a családi erôszakkal kapcsolatos esetekkel. Az Igazságügyi Minisztérium kezdeményezésére létrejött a Társadalmi Bűnmegelőzési Stratégia elnevezésű program, melyben külön részt szentelnek a családban előforduló erőszak problémájának kezelésére, további országgyưlési, kormány és rendőrfőkapitányi határozatok és utasítások szabályozzák a konfliktusos családi viszonyokat. ${ }^{29}$ Elmondható, hogy jogszabályi szinten modernnek számító gyermekvédelmi törvényünk van. A Ptk. Családjogi Könyve alapelveivel is körbebástyázza mind a gyermeket, mind a családot. ${ }^{30}$ Van távoltartási törvényünk, ${ }^{31}$ családon belüli erőszakot szabályozó törvényünk, ${ }^{32}$ mégis a gyakorlatban nincs hatékony együttműködés az egyes hatóságok között, nincs hatékony ügykezelés azoknál az eseteknél, ahol emberi sorsok jobbrafordulása lenne a sürgetô cél.

Számos áldozatvédelmi program is múködik ma Magyarországon, de a leglényegesebb, hogy a Btk. 212/A. \-ában szabályozva lett az ún. kapcsolati erőszak is. ${ }^{33}$ Vagyis jogász szemmel nyugodtak lehetünk, a gyakorlat azonban aggasztó tüneteket mutat. Fontos feladat lenne hidakat építeni az egyes szakmai területek között. Fontos lenne a jelzőrendszert jól múködtetni. Ha szakemberek és a közember is érzékenyítve lenne, ismerné jogait, kötelességeit, mernének talán az emberek felelősen cselekedni, segítséget kérni

A nehézkesen múködő segítőrendszerek szükségessé teszik, hogy a kisebb csoportok vagy akár az egyén is vállára vegyen a társadalom nehézségeiből. Vagyis olyan felelősségtudatot kell a lehető legkisebb kortól átadni az új generációknak, amely a fókuszt az elfogadásra, az odafordulásra, a közösségi együttmúködésre helyezi. Mindenki tegyen azért, hogy a saját környezetében valami jobbá legyen. Az érzékenyítő foglalkozások segítik elfogadni az egészen fiatalokkal is, hogy

\footnotetext{
29 45/2003. (IV.16) országgyűlési határozat; 34/2002.(BK.24) belügyminisztériumi utasítás; 13/2003 országos rendőrfőkapitányi intézkedés/ módszertani útmutató; Btk 137.\$(6) bek. alanyi kör meghatározása; 115/2003 országgyülési határozat a Társadalmi Bűnmegelőzési Stratégia programról; 1009/2004(II. 26) Kormány határozat a stratégia végrehajtásáról. 2009. évi LXXII. törvény a megelőző távoltartásról. Be. 138/A-139.』 az eljárásban elrendelhető távoltartásról. Btk. 212/A. \a kapcsolati erőszak tényállása. 2/2018.(I.25) ORFK utasítás a hozzátartozók közötti erőszak kezelésével összefüggő rendőrségi feladatok végrehajtásáról.

30 Ptk.4:1-4. SS

31 2009. évi LXXII. törvény, Be. 138/A-139.S

32 Btk. 212/A. \

${ }^{33}$ GILÁNYI, A családon belüli erôszakkal kapcsolatos jogszabályalkotás Magyarországon 12-14.
} 
mindannyian valamiben mások vagyunk, ebben a másságunkban akár az erőnk is lehet egykor. Különösen égető feladat ez idehaza, ahol a másképp múködő személyeket zárt intézetek falai takarták a világ elől még a 1980-as években is. A fogyatékos, hajléktalan emberek látványa szinte ismeretlen volt még a gyerekkoromban is, ma azonban az erőfeszítések ellenére is kitűnik, hogy maga a társadalom nincs felkészülve a fogyatékosság vagy a hajléktalanság kezelésére.

A témával foglalkozó kutatók számára elsősorban empirikus szociológiai és kriminológiai magyar felmérések állnak rendelkezésre. Egyre közelebb kerülünk a családi erőszak teljeskörű, minden szakterületet érintő feltérképezéséhez. A családi konfliktusok talán legkiszolgáltatottabb áldozatai a gyermekek lehetnek. Sorsuk alakulása az elszenvedett traumák után csakis az őket patronáló felnőttek kezében van. Ez a teljes kiszolgáltatottságából adódó helyzet különös körültekintést kíván a kiskorúval foglalkozó szakemberektől, szülőktôl. Felelősséggel kell megválasztani a gyermekek szempontjaiból is legalkalmasabb rehabilitációs terápiát. A cél megvalósítása azonban számos nehézségbe ütközhet. Kérdéses, hogy modern értelemben vett család- és gyermekvédelmi rendszernek lehet-e tekinteni a magyar megoldást, miközben modern maga a jogszabályi háttér, ami rendelkezésünkre áll. ${ }^{34} \mathrm{~A}$ módszerek bevezetésével párhuzamosan sajátítják el a szakemberek az alkalmazandó feladatokat. Az előbbiekből kitűnik, hogy számos és folyamatos kezdeményezés indult mind az állami, mind a civil csoportok részérôl is. Hiányzik még az együttmúködésből a két oldal között a kölcsönönös kommunikáció. Ezen kívül elengedhetetlenül szükséges az anyagi és tárgyi feltételek megteremtése, valamint a rendőrök és a gyermekvédelemben dolgozók folyamatos áldozatvédelmi érzékenyítése.

\subsection{FRIG}

Hasznos és Magyarország szempontjából előremutató az Amerikai Egyesület Államokból, Minesotaból származó Domestic Abuse Intervention Project néven ismert rendszert, melyet már számos nyugat-európai országban, köztük Ausztriában, Svájcban és Németországban is sikeresen alkalmaznak. Gyakorlatomat magam is egyik csoportjuknál (Freiburger Interventionsprojekt gegen bäusliche Gewalt $t^{35}$ ) végeztem Freiburgban. A koncepció lényege abban áll, hogy egy asztalhoz ültessük a családi erôszakkal foglalkozó hatóságokat és intézményeket. A szervezet elsődleges feladata ennek az együttes munkának a koordinálása és összehangolása. Fő céljuk az áldozatok, elsősorban nôk és gyermekek biztonsága és védelme, második helyen áll az elkövetôvel szembeni polgári jogi vagy büntetőjogi eljárás megindításának kezdeményezése. Nem elhanyagolható a nyilvánosság figyelmének felkeltéséért végzett munkájuk sem, hisz igyekeznek a társadalmi keretfeltételek között gátat szabni a családon belüli erőszak terjedésének, és ennek érdekében a lakosságot érzékennyé tenni a téma iránt. Szintén fontos küldetésnek tekintik az intervenciós csoportok az elkövetői oldal támogatását. Anti-erőszak tréningek indításával törekednek a hatékonyabb családgyógyításra. Egy-egy ilyen szervezet az összehangolt intervenciósstratégiára épülő munkát területi szinten, azaz meghatározott régióban végzi, része a helyi kriminálprevenciós programnak, és tevékenységét felelős civil és állami intézmények támogatják. Hetente összehívják

${ }^{34}$ Lásd a gyermekek védelméről és a gyámügyi igazgatásról szóló 1997. évi XXXI. törvényt valamint Új Ptk. Családjogi Könyvének vonatkozó rendelkezéseit.

${ }^{35}$ www.frig-freiburg.de 
egy kerekasztal megbeszélésre az érintett szervezetek képviselőit, hogy az előttük álló feladatokat összehangoltan és hatékonyan végezhessék. Céljuk egy optimális intervenciós hálózat megvalósítása, kétoldalú - az áldozatnak és az elkövetőnek nyújtott - segítség felkínálásával. A hasonló területi adottságokkal és jogrendszerrel rendelkező Ausztria példáján felbuzdulva Magyarország számára is sikeres megoldás lehetne a DAIP koncepciójának tényleges átvétele a gyakorlatba.

Magyarország számos tehetséges emberrel gazdagította és gazdagítja ma is a világot. Ugyanakkor történelmi pozíciójánál fogva sokszor maradt alul. Hiszek benne, hogy tehetséges embereink, akaratunk és összefogásunk által sikerül mielőbb lemaradásainkat feldolgozni, és így egyre hatékonyabban tehetünk a felnövekvő új generáció jólétéért. Ettől a meggyőződéstől vezérelve zárásként két sikeres magyar módszert fogok bemutatni, melyekkel a későbbiekben talán épp a családon belüli erőszak visszaszorításánál is sikereket lehetne elérni.

\subsection{Intrauterin kommunikáció}

Az első technika már a terhességi időszakban megkezdi a szülő és gyermeke közti kapcsolat kiépítését. Ez az időszak egyedülálló megelőzési lehetőségnek tűnik mind a gyermek, mind szülője számára. A tudatos szülővé válásban segítheti a későbbi konfliktusok megértőbb feldolgozását, kétségtelen bizalomépítő erején keresztül. 1995-ben, a heidelbergi Nemzetközi Pre- és Perinatális Pszichológiai és Orvostudományi Konferencián „Intrauterin (méhen belüli) anyareprezentáns” címmel ${ }^{36}$ először mutatta be két magyar pszichoanalitikus, Hidas György és Raffai Jenő az általuk kifejlesztett anya-magzat kapcsolatanalízises módszert. Az eljárás lényege a terhesség ideje alatti kommunikáció kiépítése anya és magzata között egy analitikus segítségével.

A szakemberek figyelmét a pszichotikus betegek terápiás kezelése közben előjött emlékképek hívták fel a születés előtti életszakasz jelentőségére. Ez a felismerés arra sarkallta a kutatókat, hogy elsősorban ne az egyes betegségek terápiás kezelésére, hanem sokkal inkább még a születés előtt kínálkozó megelőzésre koncentráljanak. A több mint kétszáz kismamával elvégzett kísérlet azóta felkeltette a pszichológia szaktekintélyeinek érdeklődését is. A modern tudomány eszközei segítették a megfigyelések elvégzését, melyekkel a magzat élettere alaposan megfigyelhetővé vált. Bebizonyosodott, hogy a fejlődésben lévő embriókat a kezdetektől információk özöne éri, és lényegesen többet érzékelnek a külvilágból érkező ingerek közül, mint ahogy azt korábban feltételezték.

A legújabb kutatások azt igazolják, hogy az anya születendő gyermekével kapcsolatos beállítódásai meghatározóak a baba fejlődésére. Az édesanya esetleges depressziója, a születés előtti stresszes állapotok, a környezeti befolyások, párkapcsolati zavarok, a szülői beállítódások, konfliktusok vagy egyéb betegségek mind hatással vannak a magzatra, befolyásolhatják későbbi személyiségének alakulását. De a magzat nem csak az anya beállítódásait érzékeli, eljut hozzá a mama életében szerepet játszó személyek viselkedése, s hatnak rá a környezetében zajló események is. „Egy ember élete legalább két generációval korábban kędódik: az apai és anyai nagyszülök házában. Nem csupán a genetikai, kromoszomális feltételeket kapjuk örökeségül, banem az epigenetikusokat is, a társadalmi,

\footnotetext{
${ }^{36}$ RAFFAI, Der Intrauterine Mutterrepresentant 357-365.
} 
kultúrális feltételeket, a pszichoszociális struktúrákat." ${ }^{37}$ A magyar kutatások szerint a születést megelőző életszakasz egyedülálló megelőzési lehetőség a későbbiekben fellépő lelki, szellemi és fizikai zavarokra. A kapcsolatanalízis egy olyan módszer, melyben anya és gyermeke sorsukat már a kezdetektől tudatosan kézbe vehetik, kapcsolatukat elmélyíthetik. A szülők nem csak génjeikkel, hanem viselkedésükkel is drámai módon befolyásolják az utódok méhen belüli fejlődését. A méhen belüli gyermek bonyolult interperszonális hálóban él, és ha a rendszer valamelyik tagja nem múködik optimálisan, elsősorban a gyermek viseli annak következményeit.

Az ülések során az analitikus segítségével az anya mély, relaxált állapotba, pszichoanalitikus módszerek alkalmazásával próbál utat találni magzatához. A lelki köldökzsinór, azaz kettejük kommunikációs rendszerének kiépítésére törekedve. A vizsgálatban részt vett mamák mindegyike a babák felgyorsult értelmi és mozgásfejlődéséről számolt be a születés után, s ezt a vizsgálatban részt vett kisgyermekek intelligenciájáról készült későbbi eredmények is alátámasztják. ${ }^{38}$

A társadalom jövője a tudatos és felelősségteljes szülővé válás több generációs folyamatán múlhat. A szülővé válás elfogadásának előfeltétele, ismét felfedezni és elfogadni a bennünk lévő gyermeket minden bajával, szorongásával, félelmével együtt. Csak így sikerülhet jól és támogató módon kísérni útjukon a legkiszolgáltatottabbakat.

\subsection{Az ún. Kokas pedagógia}

A második technika a már traumát átélt gyermekek kezelésében nyújthat segítséget. Lényeges feladat egy lelki megrázkódtatásokon átesett gyermek esetében az óvatos reszocializálás és rehabiltálás. A családon belüli erőszak gyerek áldozatai szüleiktől, rokonaiktól, a családi körben, vagyis épp ott, és azoktól a személyektől szenvedtek el súlyos testi és/vagy lelki sérüléseket, akiktől az oltalmat, biztonságot várhatnák. ${ }^{39}$ Ilyen erôszakos események hatására az amúgy is kiszolgáltatott helyzetben lévő gyermek hirtelen talajt vesztetté válik, bizalma megremeg. Felállítása a szakemberektől nagyon nagy figyelmet, hozzáértést követel.

A verbális formában alkalmazott segítő módszerek ezeknél a gyerekeknél könnyebben vezethetnek másodlagos viktimizációhoz. ${ }^{40}$ Elég egy rosszul fogalmazott mondat, és könnyen újra élik a nehéz emlékeket, ha óvatlan a szakember. Ezért igyekeztem olyan magyar módszert találni, ami épp a non-verbális elemek alkalmazására építve, óvatosabban, és a foglalkozást vezető szempontjából biztonságosabban képes gyógyítani.

A következőkben egy olyan magyar zenepedagógiai technikát fogok felvázolni, melyet Kokas Klára ${ }^{41}$ nemzetközileg elismert magyar zenepedagógus, Kodály Zoltán tanítványa hozott létre. A módszer bázisát egyrészt a kodályi eszme szerinti nemzeti tradíciókhoz való visszanyúlás, valamint az ôsi kultúrákhoz való visszatérés képezi, ahol a zene és mozgás még egységes egész, egymástól nem elválasztható volt. ${ }^{42}$ A foglalkozások csoportban zajlanak. A résztvevők - akik

\footnotetext{
${ }^{37}$ HIDAS - RAFFAI - VOLLNER, Lelki köldökzsinór 45.

38 RAFFAI, Csecsemők jobb fejlődési esélyei kapcsolatanalízisben 193-199.

${ }^{39}$ RANSCHBURG, A meghitt erőszak 15-20.

40 KORINEK, Kriminológia I. 352-355.

${ }^{41}$ LÁSD https://kokas.hu/ KOKAS Klára felhasznált cikkei a honlapról: Az érzelmek figyelme; A tanítás művészete; Egymásra figyelve.

${ }^{42}$ KOKAS, Gyerekekkel Kodály nyomában, http://www.parlando.hu/Kokas2.htm.
} 
elsősorban 3 és 10 év közötti kisgyermekek - ismételt zenehallgatás révén a muzsika mélyebb befogadását sajátíthatják el. Non-verbális eszközök segítségével ${ }^{43}$ - mozgással, rajzolással, festéssel és agyagozással - kifejezhetik az elhangzott mű nyomán keletkezett ihletüket. Az egymás szeme láttára létrejött mozgássorok, vagy rajzok formájában megszólaló mély lelki kitárulkozásnak komoly közösség kovácsoló, személyiségfejlesztő ereje van. Az integráció az egyik legfontosabb elve Kokas Klára munkájának. A zene segítségével mindenki egyfajta belső utazását él meg. Ami az épp önmagát megmutatótól a másik iránti bizalmat, a befogadóféltöl pedig a társa iránti empátiát felételezi. A közösséggel fontos elfogadtatni a másságot, a másik ember egyediségét. Nincsenek különválasztva azok a gyermekek, akiket egyébként testi, lelki vagy érzelmi sérüléseik miatt másutt megkülönböztetnének, épp ellenkezőleg. A tolerancia, az empatikus figyelemre nevelés, s a másik ember érzéseinek elfogadása lényeges szempontja a módszernek. Kokas hite szerint alapvető emberi joga mindenkinek a megnyilatkozás szabadsága, továbbá feladatunk saját sorsunk irányításának megtanulása, e folyamat fejlesztése is a foglalkozás céljai között szerepel. A közösségi foglalkozások, az integráció, a tolerancia, a megnyilatkozás szabadsága, mind olyan lényeges elem, mely nagy segítségére lehet egy lelkileg súlyos sérülést elszenvedett gyermeknek. A Kokas-módszer ${ }^{44}$ mindezeken túl bevezetést nyújt a zene rejtelmes világába.

Összefoglalva tehát, a gyermekek csoportjukban az előre kiválasztott zenedarabot többszöri ismétléssel meghallgatják. Az irányító zenepedagógus segítségével elkezdik a benyomásaikat, a zene által keletkezett érzéseiket a hallott dallamokról kifejezni non-verbális eszközökkel. A módszer megkívánja a kicsiktől, hogy saját önkifejezésükön túl társaikra is figyeljenek. Megértsék a másik üzenetét, amely esetenként személyes, mélyen elnyomott történeteket hoz elő. A pedagógus dolga, hogy érzékelje a gyermek spontán, a zene hatására beindult reakcióit, inspirálja, de ne befolyásolja megnyilatkozásában. Amikor a rajzok elkészültek, a mozgásban kifejezték a zene keltette érzéseiket, történetüket kedvük szerint elmesélhetik társaiknak, közösen megbeszélhetik azt. (Volt olyan kisfiú, aki rajzban, majd mozgásban tudta autóbalesetben meghalt édesapjának hiányát kifejezni, majd a többiekkel, a több éve mélyen elnyomott fájdalmát, érzéseit megosztani.) A pozitív megerősítés segítségével, mégis önállóan végzett feladat önbizalom növelő hatása tagadhatatlanul nagy. A foglalkozás hatásai véleményem szerint különösen jól elősegíthetnék a családban erőszakot megélt gyermekek gyógyulását. Az integráció, a toleranciára nevelés, a szabad megnyilatkozás lehetősége, a saját sorsunk irányítása és nem utolsó sorban hasznos zenei ismeretek, mind olyan kulcsmotívumok, melyek fontos eszközei a traumatizált gyermekek rehabilitációjának ${ }^{45}{ }^{46}$. A rendszer terápiás célú alkalmazását a debreceni családsegítő szolgálatnál már felnőtteknél is megkezdték. Tudomásom szerint kifejezetten családon belüli erőszak áldozatainál még eddig nem használták ezt a zenére épülő technikát, bízom benne ez is mielőbb bekövetkezik.

Ma Magyarországon számos Kokas-műhely működik, különböző életkorú gyerekekkel. Pécsen ${ }^{47}$ Fleck Erika ${ }^{48}$ zenepedagógus által vezetett Kokas-csoport múködik. A tanárnő 1999-ben kezdte el a kokasi pedagógiát alkalmazni, és sikerült egyedüliként az eredetileg 3-10 évesekre

\footnotetext{
43 Vö. KOKAS, Képességfejlesztés zenei neveléssel 20-114.

${ }^{44} \mathrm{Vö.} \mathrm{KOKAS,} \mathrm{Amerikában} \mathrm{tanítottam} \mathrm{10-80.}$

${ }^{45}$ KOKAS, Gyermekek zene-befogadása és önkifejezése különböző művészetformákban 12-20.

${ }^{46}$ Vö. BACK UP THE CHILDREN! - ÁLLJ MELLETTE! A traumatizált gyermekek támogatásának alapjai.

47 Jókai Utcai Általános Iskola, 7622 Pécs, Jókai utca 49.

${ }^{48}$ FLECK, http://www.parlando.hu/Fleck-Kokas.html.
} 
tervezett módszert átültetnie a tizenéves korosztály számára is. ${ }^{49} \mathrm{~A}$ kamaszkor testileg és lelkileg különösen nehéz időszak. Egy átmenet, amikor a személyiség gyermekből felnőtté kezd érni, egy feszültségpont a két életszakasz között. De különlegessége is épp ebben rejlik, talán az emberi életút során soha máskor nem tapasztalható bonyolult sokszínűség jellemzi. Maga a crescendo, nehezen előcsalogatható, de monumentális erejú. S mi sem példázza jobban Fleck Erika különös elhivatottságát, minthogy a szép zene segítségével sikerült megszólítania ezeket a fiatalokat. Látva ezeknek a gyerekeknek a zene hatására történt kinyílását, hiszem, hogy a zene akár az egyik eszköz lehetne a bántalmazott gyermekek gyógyításában. Létezik számos kiváló magyar módszer, élni kell velük és mindenkinek a maga környezetében megtalálni a segítségnyújtás leginkább kézzelfogható módját.

\section{Következtetések}

Naivitás lenne azt feltételezni, hogy az erőszak valaha is teljes mértékben megszüntethetô lehet, de törekedni kell a szakembereknek, szülőknek, felnőtteknek egyaránt, hogy minél inkább megóvják a családokban, vagy azon kívül nevelkedő gyermekeket a korai súlyos traumák megtapasztalásától. A már elszenvedett sebek pedig nem maradhatnak kezeletlenül, mert túlzás nélkül a jövőnk a tét. „,...) Ha otthon a gyülölet légköre uralkodik, akekor a gyerek nem fog semmit elfogadni, vagy minden squándék az. ellenkezójébe fordul, és a gyerek rombolni fog, ösæintétlen les₹. Megpróbálom a sqülókkeel megérteni, hogy rajtuk múlik az emberiség jöröje. Ha folytatják gyerekeik életerejének rombolását önkényes tekintélyük eröszakolásával, akkor csak a bünözés, a báború, a nyomorúság fog folytatódni. Ha folytatják, akekor el fogják veszteni a gyerekeik szeretetét, mert senki nem szereti ažt, akitöl fél. A gyerekek bölcsek: a szeretetre szeretettel, a gyülöletre gyülölettel reagálnak. A szeretetre úgy, hogy ha az valódi akekor képesek lesžnek az önfegyelemre a családban (...). ’50

\section{Felhasznált források és irodalom}

1997. évi XXXI. tv. a gyermekek védelméről és a gyámügyi igazgatásról

2013. évi V. tv. a polgári törvénykönyvről = új Ptk.

45/2003.(IV.16) országgyúlési határozat

34/2002.(BK.24) belügyminisztériumi utasítás

13/2003 országos rendőrfőkapitányi intézkedés/ módszertani útmutató

115/2003 országgyúlési határozat a Társadalmi Bűnmegelőzési Stratégia programról

1009/2004 (II. 26) kormányhatározat a stratégia végrehajtásáról

2009. évi LXXII. tv. a hozzátartozók közötti erőszak miatt alkalmazható távoltartásról

2/2018. (01. 25.) ORFK utasítás a hozzátartozók közötti erőszak kezelésével összefüggő rendőrségi feladatok végrehajtásáról.

XI. Pius pápa Quadragesimo anno... kezdetű enciklikája. Acta Apostolicae Sedis XXIII. 1931 http:/ / tarsadalomformalas.kife.hu/xi-pius-papa-quadragesimo-anno/ (letöltve: 2018. 12. 01.)

Back up the children! - Állj mellette! A traumatizált gyermekek támogatásának alapjai. Segédanyag az oktatófilmhez. http://nane.hu/wp-content/uploads/2016/03/ALLJ_MELLETTE_WEBRE.pdf (letöltés: 2018. 12. 01.)

BALOGH Jenő: Fiatalkorúak és a büntetőjog. Budapest 1905

\footnotetext{
${ }^{49}$ FLECK Durch bewegten Hören Musik erfarber machen 24-27.

${ }^{50}$ NeIL, A radical approach to child rearing 18-30.
} 
CAINE, Barbara: English Feminism, 1780-1980. Oxford 1997

CSÁSZÁR Kinga: Nőmozgalmak a dualizmus-kori Magyarországon (1867-1918). Jura 2013/1. sz. 117-128.

FLECK Erika: Tanítványok - A „Szép Kelet, Szép Nap” - Országos Zenepedagógiai Szimpóziumon elhangzott előadása. Pécs 2002

FLECK Erika: Durch bewegten Hören Musik erfarber machen - Neue Musikzeitung 2003/10. sz. 24.

GILÁNYI Eszter: A családon belüli erőszakkal kapcsolatos jogszabályalkotás Magyarországon. In: Collega; Az Accursius Jogász Egylet folyóirata IX. évf. 2. sz. 98.

ENGELS, Friedrich: A család, a magántulajdon és az állam eredete. Budapest 1975

HerCzog Mária: Gyermekbántalmazás. Budapest, 2007

HERGER Csabáné: A modern magyar házassági vagyonjog kialakulása és rendszere a német jogfejlődés tükrében. Passau 2017

HERGER Csabáné: Szakrális kontra szekuláris értékek a polgári modernizáció korában. Díké 2017/1. sz. 33-44.

HIDAS György - RAFFAI Jenő - VOLLNER Judit: Lelki köldökzsinór. Budapest 2015

HORVÁTH Attila: A szovjet család- és házasságjog.

http://www.rubicon.hu/magyar/oldalak/a_szovjet_csalad_es_hazassagjog/ (letöltve: 2018. 12. 01.)

KEREZSI Klára: A védtelen gyermek. Erőszak és elhanyagolás a családban. Budapest 1995

KOKAS Klára: Képességfejlesztés zenei neveléssel - Improving Talents trough Musical Education. Editio Musica 1972

KOKAS Klára: Gyermekek zene-befogadása és önkifejezése különböző művészetformákban: Kodály-i segítség a problematikus gyerekek nevelésében. Kecskemét 1984

KOKAS Klára: Amerikában tanítottam - I Taught in America. Editio Musica 1978

KOKAS Klára: Gyerekekkel Kodály nyomában. Parlando 2004/1. sz. http://www.parlando.hu/Kokas2.htm

KORINEK Beáta: A családból fakadó erő. In: FINSZTER Géza (szerk.) Egy jobb világot hátrahagyni...Tanulmányok Korinek László professzor tiszteletére. Pécs 2016

KORINEK Beáta: A stalkingról. In: Kőhalmi László (szerk.): Emlékkönyv Irk Albert születésének 120. évfordulójára Pécs 2004

KORINEK Beáta: Egyenlő esélyek büntetéssel? In: SOMFAI Balázs (szerk.): Ünnepi tanulmánykötet Filó Erika kandidátus egyetemi docens 70. születésnapjára. Pécs 2010, 109-122.

KORINEK László: Kriminológia I. Budapest 2010

KOSÁRY Domokos: Az oktatásügy a haladó törekvések hullámvölgye idején (1790 - 1830). In: HoRVÁTH Márton (szerk.): A magyar nevelés története I. Budapest 1988, 211-255.

KŐRÖS András: Polgári jog. Családjog. Az új Ptk. magyarázata III/IV. Budapest 2014

LORENZ, Konrad: Das sogennante Böse. Zur Naturgeschichte der Agression. Bécs 1963

LÖW Tóbiás (szerk.): A Magyar Büntetőtörvénykönyv a bűntettekről és vétségekről és teljes anyaggyűjteménye. I. Budapest 1880

MÓRICZ Zsigmond: Árvácska, Kelet Népe/1940.

NAGYIVÁNYI-FEKETE Gyula: Az elhagyott gyermekek és fiatalkorú bűntettesek gondozása. Budapest, 1893.

NEIL, Alexander Sutherland: Summerhill. A radical approach to child rearing. kiadás helye 1960

NizSALOVSZKY Endre: Gesetz und Wirklichkeit im sozialistischen ehelichen Gütterrecht. Budapest 1970

PERKIN, Joan: Women and Marriage in Nineteenth-Century England. Routledge 1989

RAFFAI Jenő: Der Intrauterine Mutterrepresentant. In: J. Prenat and Perinat Psychology and Medicine 1995/8. sz. 357365.

RAFFAI Jenő: Csecsemők jobb fejlődési esélyei kapcsolatanalízisben. Pszichoterápia IX. évf. 3. sz. 193-199.

RANSCHBURG Jenő: A meghitt erőszak. Budapest 2006

TAMÁsI Erzsébet: Bűnös áldozatok. A családon belüli erőszak férfi szereplői. Budapest 2005

http://www.rubicon.hu/magyar/oldalak/1493_november_11_paracelsus_szuletese (lelöltve: 2018. 12. 01.) 